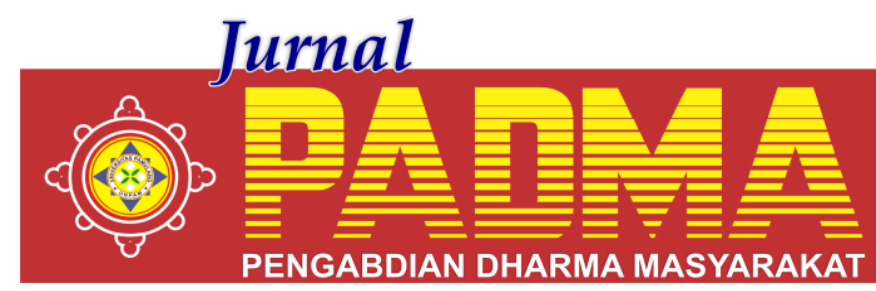

VOLUME 1, NOMOR 4, OKTOBER 2021

\title{
PENYULUHAN MANAJEMEN SUMBER DAYA MANUSIA UNTUK PENGEMBANGAN KARIR PASCA KELULUSAN SEKOLAH SMK PLUIT RAYA PENJARINGAN JAKARTA UTARA
}

\author{
${ }^{1}$ Ainun Fitri, ${ }^{2}$ Febryanti Novita Sari, ${ }^{3}$ Fiqqih Yunnus Pratama, ${ }^{4}$ Husnul Fathiyyah Baswati \\ Putri, ${ }^{5}$ Novika Sani, ${ }^{*}$ Aidil Amin Effendy \\ Universitas Pamulang, Tangerang Selatan, Banten, Indonesia \\ *aidil00967@unpam.ac.id
}

\begin{abstract}
Abstrak
Pengembangan diri dengan membentuk karakter diri, mengelola kemampuan yang dimiliki, meningkatkan pengetahuan dan keterampilan diri dan mampu menciptakan kesiapan membuat keputusan karir yang tepat bagi masa depan dan menumbuhkan motivasi bagi para siswa-siswi agar bisa merangsang keaktifan dan kreativitas siswa-siswi, dimana perencanaan karir adalah sesuatu yang menyangkut masa depan dalam jangka panjang yang harus direncanakan sejak jauh hari, merencanakan kemana seseorang ingin melangkah dan apa yang ingin dicapai.
\end{abstract}

Kata Kunci: Pengembangan Diri, Perencanaan Karir

\section{Abstract}

Self-development by forming self-character, managing the abilities possessed, increasing knowledge and skills and able to create readiness to make career decisions that are right for the future and foster motivation for students to stimulate the activeness and creativity of students, where career planning is something that concerns the future in the long term that must be planned from a long time, planning where one wants to go and what they want to achieve.

Keywords: Self-development, Career planning

\section{PENDAHULUAN}

Perencanaan sangatlah penting bagi seseorang yang ingin memulai suatu kegiatan maupun mengambil keputusan tentang hal yang ingin dijalaninya. Akan tetapi perencanaan yang matang menuntut pemikiran yang kuat terhadap segala tujuan yang ingin dicapai dalam jangka waktu panjang dan jangka waktu pendek. Jangka waktu panjang merupakan gaya hidup yang akan dicapai dan nilai-nilai kehidupan yang ingin direalisasikan dalam kehidupan. Sedangkan jangka waktu pendek merupakan tujuan yang hendak dicapai dalam bentuk akhir suatu kegiatan,seperti ijazah atau sertifikat yang ingin diperoleh untuk mempersiapkan diri memegang jabatan tertentu dikemudian hari. Perkembangan zaman yang semakin modern terutama pada era globalisasi saat ini menuntut adanya sumber daya manusia (SDM) yang berkualitas. Salah satu wahana untuk meningkatkan kualitas SDM tersebut adalah pendidikan. Dengan pendidikan maka kualitas manusia diubah ke arah yang lebih baik dan menjadikannya sumber daya yang berguna bagi dirinya maupun bagi masyarakat.

Keinginan, minat, ataupun keputusan siswa dalam menentukan pilihan untuk bekerja atau melanjutkan pendidikan ke jenjang yang lebih tinggi dipengaruhi oleh banyak faktor diantaranya adalah faktor internal dan faktor eksternal. Faktor internal merupakan faktor yang berasal dari dalam diri siswa seperti kemampuan, bakat, kepribadian, kecerdasan dan sebagainya. Sedangkan faktor eksternal merupakan faktor yang berada di luar siswa seperti guru, orang tua, teman sebaya, lingkungan sekitar, dan lain-lain. Faktor-faktor tersebut mampu memberikan pengaruh baik positif maupun negatif kepada siswa setelah lulus dalam menentukan pilihannya.

Pengembangan diri adalah suatu proses pembentukan potensi, bakat, sikap, perilaku dan kepribadian seseorang melalui pembelajaran dan pengalaman yang 
dilakukan berulang-ulang sehingga meningkatkan kapasitas atau kemampuan diri sampai pada tahap otonomi (kemandirian).

Pengembangan diri merupakan kegiatan pendidikan di luar mata pelajaran sebagai bagian integral dari kurikulum sekolah. Pengembangan diri menjadi salah satu upaya yang dilaksanakan di setiap lembaga pendidikan dengan mengacu pada kurikulum yang telah dirumuskan di lembaga tersebut. Namun demikian, pelaksanaan kegiatan pengembangan diri lebih banyak menggunakan waktu di luar jam pelajaran formal. Pengembangan diri adalah kegiatan konseling dan ekstrakurikuler yang bertujuan untuk memberikan kesempatan peserta didik untuk mengembangkan dan mengekspresikan diri sesuai dengan potensi, kebutuhan, bakat dan minat, serta karakteristik peserta didik. Kegiatan pengembangan diri dilaksanakan dalam bentuk pelayanan konseling (kehidupan pribadi, sosial, kesulitan belajar, karir) dan juga pengembangan kreativitas kepribadian siswa, seperti: kepramukaan, kepemimpinan dan ekstrakurikuler lainnya. Pengembangan diri merupakan proses yang utuh dari awal keputusan sampai puncak sukses dalam mencapai kemandirian serta menuju pada aktualisasi diri. Perubahan dan perkembangan bertujuan untuk memungkinkan orang menyesuaikan diri dengan lingkungan di mana dia hidup.

Menurut Amri (2013), tujuan kegiatan pengembangan diri bagi individu adalah sebagai berikut :

\section{a. Tujuan umum}

Pengembangan diri secara umum bertujuan memberikan kesempatan kepada peserta didik untuk mengembangkan dan mengekspresikan diri sesuai dengan kebutuhan masyarakat, kebutuhan peserta didik dan pembelajaran, potensi, bakat, minat, kondisi dan perkembangan peserta didik dengan memperhatikan kondisi sekolah atau madrasah.

\section{b. Tujuan khusus}

Pengembangan diri secara khusus bertujuan menunjang pendidikan peserta didik dalam mengembangkan bakat, minat, kreativitas, kompetensi maupun kebiasaan dalam kehidupan, kemampuan kehidupan keagamaan, kemampuan sosial, kemampuan belajar, wawasan dan perencanaan karir, kemampuan pemecahan masalah dan juga kemandirian.

Faktor Pengembangan Karir dimana Menurut Siagian (2006:215), terdapat tujuh faktor yang mempengaruhi pengembangan karir seseorang, yaitu sebagai berikut :

1. Prestasi kerja yang memuaskan. Pangkal tolak pengembangan karir adalah seseorang adalah prestasi kerjanya melakukan tugas yang dipercayakan kepadanya. Tanpa prestasi kerja yang memuaskan, sulit bagi seorang pekerja untuk diusulkan oleh atasannya agar dipertimbangkan untuk dipromosikan ke pekerjaan atau jabatan yang lebih tinggi di masa depan.

2. Pengenalan oleh pihak lain. Yang dimaksud di sini adalah berbagai pihak yang berwenang memutuskan layak tidaknya seseorang dipromosikan seperti atasan langsung dan pimpinan bagian kepegawaian yang mengetahui kemampuan dan prestasi kerja pegawai.

3. Kesetiaan pada organisasi. Merupakan dedikasi seorang pegawai yang ingin terus berkarya dalam organisasi tempatnya bekerja untuk jangka waktu yang lama.

4. Pembimbing dan sponsor. Pembimbing adalah orang yang memberikan nasihat-nasihat atau saransaran kepada karyawan dalam upaya mengembangkan karirnya. Sedangkan sponsor adalah seseorang di dalam perusahaan yang dapat menciptakan kesempatan bagi karyawan untuk mengembangkan karirnya.

5. Dukungan para bawahan. Merupakan dukungan yang diberikan para bawahan dalam bentuk mensukseskan tugas manajer yang bersangkutan.

6. Kesempatan untuk bertumbuh. Merupakan kesempatan yang diberikan kepada karyawan untuk meningkatkan kemampuannya, baik melalui pelatihanpelatihan, kursus, dan juga melanjutkan jenjang pendidikannya.

7. Berhenti atas permintaan dan kemauan sendiri. Merupakan keputusan 
seorang karyawan untukberhenti bekerja dan beralih ke perusahaan lain yang memberikan kesempatan lebih besar untuk mengembangkan karir.

Setiap organisasi apapun bentuknya senantiasa akan berupaya dapat tercapainya tujuan organisasi yang bersangkutan dengan efektif dan efisien. Efisiensi maupun efektivitas organisasi sangat tergantung pada baik buruknya pengembangan sumber daya manusia atau anggota organisasi itu sendiri. Ini berarti bahwa sumber daya manusia yang ada dalam organisasi tersebut secara proporsional harus diberikan latihan dan pendidikan yang sebaik-baiknya, bahkan harus sesempurna mungkin. Pengembangan pada umumnya lebih bersifat filosofis dan teoritis, dibandingkan dengan kegiatan pelatihan. Lagi pula pengembangan lebih diarahkan untuk golongan manajer, sedangkan program pelatihan ditujukan untuk golongan non manajer. Meskipun keduanya ada perbedaan, namun perlu disadari bahwa baik latihan (training) maupun pengembangan (development) keduanya menekan peningkatan keterampilan ataupun kemampuan dalam human relations.

\section{METODE}

Agar program ini berjalan secara maksimal, maka di perlukan perencanaan secara tepat di antaranya menyusun proposal kegiatan dalam penyuluhan manajemen sumber daya manusia untuk pengembangan karir pasca kelulusan, mengetahui manfaat yang ada jika para siswa/i ikut andil dan analisis keaktifan mereka untuk pengembangan diri, mengamati pentingnya mengadakan program penyuluhan terhadap siswa/i karena latar belakang pasca kelulusan yang dimiliki berpotensi, menyusun waktu pelaksanaan kegiatan, meminta izin kepada pihak yang berwenang dengan menghubungi kepala sekolah yang telah bersedia menyediakan sarana kegiatan, mempersiapkan alat dan bahan dalam memberikan penyuluhan secara online/daring, mempersiapkan siswa-siswi untuk dapat memilih keputusan yang akan di pilih setelah lulus sekolah.

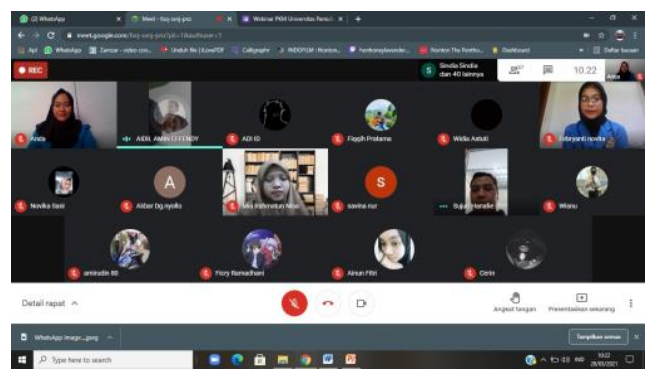

Gambar 1. Diskusi Via Google Meet

\section{HASIL DAN PEMBAHASAN}

Kegiatan ini dilaksanakan pada bulan Maret di SMK Pluit Raya. Jl. Jemb. 3 Raya No.1, RT.14/RW.8, Penjaringan, Kec. Penjaringan, Kota Jakarta Utara. Dengan pelaksanaanya secara Online/Daring. Materi yang disajikan ada 3, yaitu :

1. Karakter. Bagaimana kita membentuk karakter kita, belajar dari hal kecil disiplin waktu, menahan hawa napsu, percaya atau tidak hal-hal seperti itu bisa menjadikan diri kita menjadi pribadi yang lebih baik, pahami kekurangan dan kelebihan diri sendiri juga keyakinan pada diri kita.

2. Skill. Dimana skill dibagi menjadi dua hard skill dan soft skill. Bagaimana kita mengelola kemampuan yang kita punya, kemampuan yang selama ini kita pendam. Seperti contoh: siswa/i ada yang pandai sekali dalam menulis, kemudian dia sadar akan kemampuannya, kemudian menjadikannya hasil seperti menjadi copywriting. Atau penulis buku, ini termasuk kedalam hard skill. Lalu, jika memiliki kemampuan memimpin sesuatu, atau keterampilan komunikasi, menjadi pendengar yang baik, membangun atau memperbaharui identitas. Misalnya, seorang introvet. Tapi bukan berarti introvet tidak bisa publik speaking, justru setiap orang harus ada skill publik speakingnya. Ini termasuk kedalam soft skill.

3. Pengetahuan. Meningkatkan pengetahuan diri atau perluas relasi untuk mendapatkan info-info baru, agar sadar dunia pengetahuan itu luas. Meningkatkan keterampilan atau mempelajari keterampilan baru seperti meningkatkan hard skill dan mengembangkan bakat. 


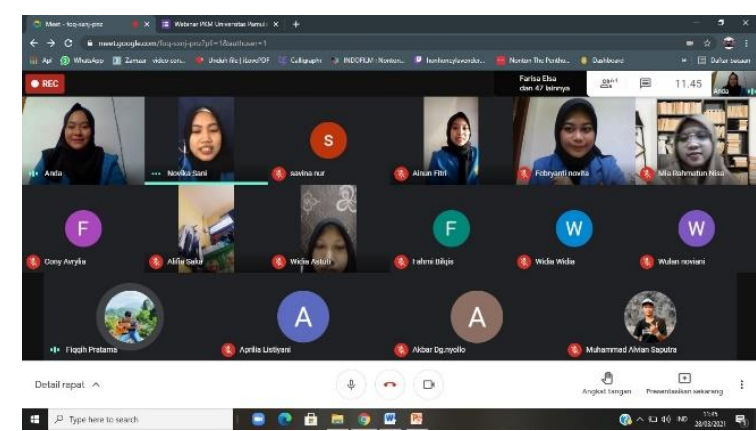

Gambar 2.

\section{PENUTUP}

Dari uraian di atas jelas, bahwa tujuan dari seluruh program pengembangan karir adalah untuk menyesuaikan antara kebutuhan dan tujuan dengan kesempatan karir yang tersedia di organisasi atau perusahaan saat ini dan di masa yang akan datang. Sehingga untuk itu usaha pengembangan sumber daya manusia dalam organisasi/perusahaan yang bersangkutan sangatlah diperlukan. Dengan demikian dapat ditarik kesimpulan, bahwa tujuan pengembangan sumber daya manusia termaksud adalah untuk memperbaiki efektivitas dan efisiensi kerja mereka dalam melaksanakan dan mencapai sasaran program-program kerja yang telah ditetapkan.

Pengabdian kepada masyarakat yang kami laksanakan guna memberikan pelatihan, gambaran ide strategi, serta memberikan motivasi agar siswa/i SMK Pluit Raya Penjaringan Jakarta Utara bisa mengembangkan diri untuk mempersiapkan masa yang akan datang apalagi pada masa pandemi Covid-19 ini.

Hasil dari Pengabdian Kepada Masyarakat ini yaitu para peserta khususnya Siswa-Siswi SMK Pluit Raya Penjaringan Jakarta Utara menjadi lebih mengerti, dan memahami serta mendapatkan ide, saran, dan strategi mengenai cara mengembangkan diri juga perencanaan karir yang dapat ditempuh untuk memasuk tahapan masa depan yang akan datang.

\section{DAFTAR PUSTAKA}

Amri, Sofan. 2013. Peningkatan Mutu Pendidikan Sekolah Dasar dan Menengah dalam Teori Konsep dan Analisis. Jakarta: Prestasi Pustakarya.
Corey, Gerald. 2005. Teori dan praktek dari konseling dan psikoterapi. Jakarta: ERESCO.

Departemen Agama. 2005. Pedoman Kegiatan Pengembangan Diri. Jakarta: Departemen Agama.

Fanani, A.C. 2003. Studi tentang Metode Belajar Mahasiswa Pendidikan Agama Islam dalam Upaya Pengembangan Diri di Fakultas Tarbiyah IAIN Sunan Ampel Surabaya Periode 2000-2002. Surabaya: Skripsi fakultas tarbiyah UIN Sunan Ampel Surabaya.

Gibson, Ivansevich dan Donelly. 1995. Organisasi: Perilaku, Struktur, Proses. Jakarta: Binarupa Aksara.

Hanadelansa, H., et al. (2019). Analisis Audit Operasional Atas Pemberian Kredit Pemilikan Rumah Pada Pt Bank Rakyat Indonesia (Persero) Tbk Kantor Cabang Panakukkang Di Kota Makassar. SENTRALISASI, 8(1), 33-42.

Marmawi. 2009. Persamaan Gender dalam Pengembangan Diri. Jurnal Visi Ilmu Pendidikan.

Rachman, Eileen dan Savitri, Sylvina. 2009. Anda Bisa! Menciptakan Masa Depan: Anda Sutradaranya!. Jakarta: Gramedia Pustaka Utama.

Siagian, Sondang P. 2004.Prinsip-prisip Dasar Manajemen Sumber Daya Manusia. Jakarta: Binarupa Aksara.

Soetjipto, Budi W, dkk. 2002. Paradigma Baru Manajemen Sumber Daya Manusia. Yogyakarta: Amara Books.

Sulistyowati, Endah. 2012. Implementasi Kurikulum Pendidikan Karakter. Yogyakarta: Citra Aji Parama.

Sunarsi, D. (2018). Analisis Motivasi Kerja Tenaga Pendidik Sukarela Pada Pusat Kegiatan Belajar Masyarakat (PKBM) Bimasda Kota Tangerang Selatan. Kreatif: Jurnal Ilmiah Prodi Manajemen Universitas Pamulang, 6(2), 53-65.

Tarmudji, Tarsis. 1998. Pengembangan Diri. Yogyakarta: Liberty Yogyakarta.

Wilson, Bangun. 2012. Manajemen Sumber Daya Manusia. Jakarta: Erlangga.

Winkel, W.S dan Hastuti, Sri. 2006. Bimbingan dan Konseling di Institusi Pendidikan. Jakarta: Grasindo. 